\title{
Folkesundhed og disciplinering \\ - kulturanalyse af en opdragelsesstrategi ${ }^{1}$
}

Af Ask Vest Christiansen

»...vi kan ikke ignorere det faktum, at mange danskere vælger en usund - og tilmed farlig - måde at leve på. Det er et populært dogme, at danskerne lever et gemytligt liv godt garneret med $\varnothing \mathrm{l}$, fed mad og smøger, og så dør vi et par år tidligere end andre men med et smil på læben. Sådan forholder det sig ikke. Mange danskere er syge længe før de dør. (...) Folkesundhedsprogrammet handler om at hjælpe mennesker ved at skabe sunde rammer for alle og sørge for, at der er hjælp til de mennesker, der har brug for den, og som $\emptyset$ nsker den. $\ll^{2}$

\section{Indledning}

I maj 1999 blev »Regeringens folkesundhedsprogram 1999-2008 « søsat under megen opmærksomhed. Nu skulle der gøres noget ved den danske overdødelighed i forhold til vore europæiske naboer. Programmets to overordnede mål er, at middellevetiden skal øges, og uligheden i sundhed skal udlignes. Sygdomme skal forebygges, og sundheden skal fremmes. Målene er, at vi skal leve længere og med »flere gode leveår «, samt at de der trækker statistikkerne ned, de der ikke har det godt, de socialt dårligst stillede, skal have det bedre. Det er svært at være uenig i disse mål. Prøv for eksempel med negationstesten: Vi skal have færre gode leveår, leve kortere og de der har det dårligt skal have det værre. Den går ikke. At stille sig tilfreds med status quo synes heller ikke at være en mulighed, den dårlige middellevetid taget i betragtning. Programmets udgangspunkt er tiltalende. Det er tilsyneladende gode og prisværdige intentioner, der ligger bag, og man må umiddelbart bifalde initiativet.

Folkesundhedsprogrammet er Nyrup-regeringernes første, større program til forbedring af danskernes sundhed. Ved dets udsendelse var det 10 år siden, Schlüters VKR-regering havde udsendt $»$ Regeringens forebyggelsesprogram «. Efter valget $\mathrm{i}$ marts 1998 indgik det i regeringsgrundlaget for SR-regeringsdannelsen, at der atter skulle udarbejdes et forebyggelsesprogram. De tre overordnede krav til programmet var, at det skulle være tværgående, indeholde mål og være tiårigt. Disse krav peger på to vigtige forhold. Nemlig for det første at der ikke blot er tale om et snævert medicinsk sundhedsprogram. Med involveringen af $i$ alt ti ministerier er det et program, der skal omfatte store dele af danskernes livssfære. For det andet betyder det, at programmet indeholder mål, at noget skal kunne måles (middellevetiden), men også at de tiltag, der præsenteres, ikke blot er at opfatte som tilbud til den danske befolkning. Det er politiske mål, der skal indfries, hvis programmet skal have succes.

Imidlertid melder der sig en række spørgsmål. Når man taler om sundhedstil- 
standen som et problem, må man naturligvis spørge: hvis sundhedstilstand taler vi om? Er det nogens konkrete sundhedstilstand, eller sigtes der mod en form for filosofisk almenhed eller en sociologisk fælleshed $?^{3}$ For hvis skyld $\varnothing$ nskes den forebyggende indsats styrket? Når idræt i programmet annonceres som et område, der skal gives $\emptyset$ get prioritet med en specifik motionspolitik, hvilken idræt tænkes der så på, og hvilken rolle skal idrætten have set med sundhedsprogrammets optik? I det hele taget kan man undre sig over, hvad det egentlig er for et projekt, der arbejdes på? Hvad er det dybest set, der bliver 'markedsført' med »Regeringens folkesundhedsprogram «? Og hvad er de kulturelle, sociale og erkendelsesmæssige implikationer, når man markedsfører en bestemt ideologi om det sunde levned, som tilfældet er med »Regeringens folkesundhedsprogram $\ll$ ?

Disse spørgsmål ønsker nærværende artikel at undersøge. Med den refleksive kulturanalyse $^{4}$ som metodisk baggrund og udgangspunkt betyder det imidlertid, at en række mulige tilgange til folkesundhedsprogrammet ikke vil blive taget i betragtning. En kulturanalyse som denne diskuterer ikke et »for« overfor et »imod « for at nå frem til passende, politiske handlingsanvisninger på sundhedsområdet. Den mener heller ikke at kunne afsløre den sande sammenhæng bag folkesundhedsprogrammet. Med afsæt i den umiddelbare undren er opmærksomheden i stedet rettet mod den selvfølgelighed, hvormed de pragmatiske handlingsanvisninger præsenteres, for at komme til en forståelse af folkesundhedsprogrammet. Den vil med andre ord vise en anden sammenhæng, et andet perspektiv. I den forstand kan tilgangen beskyldes for at være snæver og kompleksitetsreducerende. Helt bevidst belyser ana- lysen således ikke alle sider ved folkesundhedsprogrammet men hæfter sig ved dem, som den mener at kunne kaste (nyt) lys over i håbet om at rykke ved en række forudfattelser og dermed bibringe (ny) erkendelse.

Artiklens udgangspunkt er derfor regeringens folkesundhedsprogram, som indledningsvist vil blive unders $\emptyset$ gt med hensyn til brugen af livsstilsbegrebet som forklaringsramme for vor tids sundhedsproblemer. Også den generelle politiske kontekst, som programmet er opstået af, vil blive belyst her. Efterfølgende vil sundheden som en del af et moderne ordensprojekt blive diskuteret $\mathrm{i}$ lyset af de sidste 100 års ændring i sygdomsbilledet. Den (post)moderne forebyggelsestanke, med dens indbyggede (selv)overvågningsstrategi for opretholdelsen af samfundsmæssig og kropslig orden, udspringer, som vi efterfølgende skal se, heraf. Dette bringer os afslutningsvist frem til en diskussion af den nuværende sundhedspolitik og dens noget ambivalente syn på idrætten.

\section{Prosentation af Regeringens folkesundhedsprogram}

Folkesundhedsprogrammet har som ambition at være »handlingsorienteret «, så dets mål kan implementeres direkte i det daglige sundhedsarbejde og »den praktiske forebyggelse «. De to faktorer, der først som sidst ønskes ændret på, er »... den svage udvikling i danskernes middellevetid samt den sociale ulighed i sundhed.« Helt præcist er det målet, at middellevetiden i programperioden skal »... øges med mindst to år for mænd og kvinder ...«, og at der skal »... ske en betydelig mindskelse af den sociale ulighed i sundhed, udtrykt ved såvel sygelighed som dødelighed.« »Mod 
disse to problemer retter programmets to overordnede mål - og dermed hele programmets $\emptyset$ vrige mål - sig. ${ }^{5}$ Således er programmets $\emptyset$ vrige 15 delmål alle udformet, så de sigter mod indløsning af disse to hovedmål. Det gælder naturligvis også det vigtige mål 5 om kost og motion, hvor det bl.a. hedder, at:

»... manglende eller begrænset fysisk aktivitet er en risikofaktor for sygdomme. Det drejer sig om kræftsygdomme, hjerte-karsygdomme, muskel-skelet lidelser, sukkersyge, knogleskørhed m.m. En halv times daglig fysisk aktivitet for voksne og en time for børn nedsætter klart sygdomsrisikoen og dødeligheden. $\ll^{6}$

Overordnet tegner det billedet af et helt igennem ambitiøst og seriøst projekt, hvor bl.a. ambitionen om udfærdigelse af en specifik motionspolitik skal være med til at forebygge praktisk talt alle de såkaldte folke-, civilisations- eller livsstilssygdomme. Derfor er der med programmet heller ikke blot tale om »... hjælp til de mennesker, der har brug for den og som ønsker den «, som Koch antyder i det indledende citat. Folkesundhedsprogrammet er ikke et tilbud som folk kan vælge at tage imod eller lade ligge. Det indeholder netop mål, som skal nås, før den politiske ambition er indfriet.

\section{Folkesundhed og livsstil}

Begreberne folkesundhed og middellevetid fremstår nærmest synonymt $\mathrm{i}$ folkesundhedsprogrammet. ${ }^{7}$ Og middellevetiden i Danmark er ikke god nok. Hvorfor den danske middellevetid er steget væsentligt mindre end $\mathrm{i}$ andre lande, ${ }^{8}$ er imidlertid kompliceret at besvare. Gennemgår man de identificerede risikofaktorer enkeltvis, så adskiller Danmark sig ikke tilstrækkeligt fra de $\varnothing$ vrige EU-lande, til at det kan gælde som forklaring på vor ringe middellevetid. Der er altså ikke tale om, at nogen enkeltfaktor er årsag til miseren. For eksempel at danskerne ryger mere tobak eller er mindre fysisk aktive end i andre lande. ${ }^{9}$ Det er formentlig heller ikke sådan, at årsagerne kan opregnes som en sum af enkeltfaktorer, der hver for sig bidrager med hver sin lille del. Der er snarere tale om en helhed, der i sig selv er større end summen af de enkeltdele, der indgår i den. Dette er en yderst problematisk kendsgerning, fordi det at undgå eller opløse netop den type forklaringer har været et hovedværktøj i udviklingen af alle moderne videnskaber. ${ }^{10}$ Det er derfor, politikerne nu står tilbage med et svar, der handler om noget så uhåndterligt som stil. Livsstil.

Med livsstilsbegrebet er det nødvendigt at operere med en syntese, hvor én risikofaktor, for eksempel tobaksrygning, bliver forstærket, når den optræder sammen med andre, for eksempel fysisk inaktivitet, alkohol, arbejdsløshed, ugift stand, dårlig uddannelse, lav indkomst osv., til en faktor, der er større end summen af de enkelte risikofaktorer til sammen. På anden måde er det ikke til at forklare de betydelige forskelle, der viser sig i middellevetid indenfor den danske befolkning. Disse store forskelle i middellevetiden internt i den danske befolkning gør opmærksom på det forhold, at der i høj grad mangler argumenter for at slå den ufaglærte arbejder i hartkorn med skolelæreren, landmanden, advokaten, smeden og bageren, blot fordi de er danske og så give sig til at anstille betragtninger over deres middellevetid og risikofaktorer. Det synes langt mere rimeligt for eksempel at sammenligne en dansk landmand med en fransk, tysk, hollandsk og norsk. Nationalstatsbetragtningen synes i 
grunden ganske arbitrær. Alligevel henvises der en bloc til danskernes livsstil, når man i det sundhedsoplysende arbejde, såvel som i folkesundhedsprogrammet, skal forklare den dårlige danske middellevetid. Livsstilsbegrebet er en åbenlys konstruktion til forklaring af danskernes sundhedsproblemer, som var vi i samme båd. Men vi er ikke i samme båd, og forklaringen ligner derfor mere en bortforklaring. Det paradoksale er, at vi $\mathrm{i}$ andre hverdagslige sammenhænge taler om danskernes livsstile, som den selvfølgeligste ting i verden. Men når det drejer sig om at forklare sundhedsproblemer, opløses heterogeniteten til fordel for automatforklaringen om danskernes livsstil. Pointen er, at smedens livsstil kun i yderst ringe omfang kan jævnføres med bagerens, langturschaufførens, forretningsmandens eller skolelærerens. Det kan den ikke, fordi det sunde liv leves og takseres vidt forskelligt på det folkeligt-individuelle niveau. ${ }^{11}$ Når livsstilsbegrebet på det statsligt-officielle niveau alligevel finder anvendelse som forklaringsredskab, skyldes det, at man herfra er nødt til at operere på et strukturelt plan. Det er samfundslegemets sundhed, der skal forbedres, (hvilket netop er årsagen til anvendelsen af begreberne »folkesundhed « og »middellevetid «), og derfor også livsstilen der skal ændres. I dette billede er det enkelte menneske at betragte som en celle i samfundslegemet. Skal det samlede legeme derfor styrkes, må det ske gennem styrkelse af de enkelte celler. Af hensyn til samfundslegemet søger man med den generaliserende tale om livsstilen at få hver enkelt celle i tale. Og kan man ikke tale cellerne til fornuft via appellen om livsstilsændringen, så er forbud og eventuelt afgifter, de veje politikerne må gå, når de $\emptyset$ nsker livsstils- og adfærdsændringer.
Hvorfor et

\section{folkesundhedsprogram?}

Livsstilsbegrebet er i programmet snævert knyttet til folkesundhedsbegrebet. Hvor man med livsstilsbegrebet implicit vurderer befolkningen en bloc, gør man det med folkesundhedsbegrebet eksplicit. Den generelle ændring af livsstilen skal føre til en generel forbedring af folkesundheden. Det betyder ikke, at folkesundhedsbegrebet defineres i programmet. Fraværet af en definition antyder de problemer, der er med begrebet. Men sådan som folkesundhedsbegrebet er anvendt i programmet, må det forstås som en slags folkets sundhed under ét, summen divideret med antallet af indbyggere, hvilket bliver identisk med levetid eller middellevetid.

Når folkesundhedsbegrebet i dag lanceres i kampen for en sundere og lykkeligere ${ }^{12}$ befolkning, kan der ligge flere ting bag. En umiddelbar betragtning, som er logisk og plausibel i forhold til programmets oplæg, er som sagt, at der med ønsket om at øge danskernes antal af gode leveår uden langvarig sygdom og komme den sociale ulighed til livs er tale om gode og prisværdige intentioner, der vil sikre den enkelte borger et bedre helbred og dermed et bedre liv.

Men ses folkesundhedsprogrammet i sammenhæng med den øvrige socialdemokratiske politik, fremtræder det straks mere kalkulerende og mister sit prisværdige skær af næstekærlighed. Man får således øje på en række sandsynlige intentioner bag regeringens arbejde. Kort fortalt er de seneste års socialpolitiske tiltag en reaktion på velfærdssamfundets aktuelle situation. Det er tydeligvis et forsøg på at løse problemet med, at landet ikke på sigt kan finansiere det nuværende velfærdssamfund med alle dets velfærdsydelser. Problemet bliver ikke mindre af, at der er massiv op- 
bakning til at fastholde den velfærdsideologi, som velfærdssamfundet er bygget op omkring, nemlig (alles) lige ret til velfærdsydelser. Både pjecerne »Danmark som foregangsland « og »Det holdbare samfund « diskuterer dette problem, og et vigtigt element i løsningen heraf synes at være at få stadig færre på passiv forsørgelse. Vi skal have et mere »rummeligt arbejdsmarked«, som det hedder. Samtidig med at vi på den ene side sørger for, at de som ikke er erhvervsaktive aktiveres, skal vi på den anden side forebygge, at flere end højest nødvendigt bliver passive modtagere af velfærdsydelser. Selvom ændringen af den sociale lovgivning i 1998 havde været i st $\varnothing$ beskeen en tid forinden, er foregangs-landpjecerne med til at tegne optakten til bistandslovens erstatning af serviceloven, hvor forebyggelse bliver omdrejningspunktet. Hermed blev der lagt op til en mere offensiv socialpolitik som et middel til løsning af problemet med at finansiere velfærdssamfundet. Strategien ligger i forlængelse af det, der har været det dominerende ideal, det vil sige begrundelsen for al ansvarlig politisk handlen i Danmark siden starten af firserne, nemlig det samfunds$\varnothing$ konomiske balanceideal. Dette ideal, i form af balance på betalingsbalancen og balance på finansloven, har været holdepunktet for Danmarks deltagelse i den europæiske union men viser nu også sin indflydelse på det social- og sundhedspolitiske område. Det synes således at være muligt at pege på en sammenhæng mellem socialpolitikken og folkesundhedsprogrammet.

I forlængelse heraf må man være opmærksom på, at moderniseringen af velfærdsstaten ikke kun handler om forbedring af enkeltområder. Såvel serviceloven som sundhedsprogrammet kan betragtes som dele af en generel trimning af hele samfundsmaskineriet, hvor delprojekterne, der skal forbedre enkeltområder, etableres for at få hele 'maskineriet' til at køre bedre ved at få delene til at passe bedre sammen, samtidig med at skattetrykkets legitimitet bevares overfor borgerne. Hele optimeringen af samfundsmaskineriet, med forestillingen om den planlagte samfundsudvikling, er således et sindbillede på modernitetsprojektet med dets idealer om udvikling og fremskridt gennem oplysning og regulering. Det er i denne sammenhæng et paradoks, at rationaliseringen og planlægningen fortsætter parallelt med, at troen på en overordnet samfundsplanlægning á la Keynes stille siver ud. Signifikant herfor er det, at ordet 'planlægning' i vid udstrækning er skiftet ud med ordet 'tilpasning'. For en umiddelbar betragtning kunne det se ud til, at de grundlæggende handlinger bag begrebsudskiftningen er de samme. Men det terminologiske skifte indebærer implicit et skifte fra offensive til mere defensive samfundsstrategier. Det, der i dag skal tilpasses, er den måde systemet, markedet og menneskene fungerer med hinanden på - det skal foregå så glat og smertefrit som muligt. Med Max Weber kan der peges på, at de løbende ændringer, justeringer og tiltag sættes i værk for at samfundet kan fungere uden for meget vold. Weber har pointeret, at det er anvendelsen af fysisk vold, der er det konstituerende træk for fænomenet politik. ${ }^{13} \mathrm{I}$ denne påstand ligger ikke, at faktorer som $\varnothing$ konomi, religion, det sociale, det psykologiske osv. ikke kan have stor og afgørende betydning. Det kan og har de naturligvis. Men det hjælper til forståelsen af, hvad politik går ud på, at holde fast i Webers påstand: at det er den monopoliserede, fysiske voldsanvendelse, der er krumtappen for det menneskelige samvær i staten, og derfor må denne faktor medinddrages, når politiske fænomener skal forklares. Samtidig er det 
karakteristisk for den vellykkede politik, at magten ikke kommer til anvendelse. Volden skal ikke være til stede, og magten skal være så godt som usynlig. I et land hvor turistplakater har fortalt, at politiets opgave er at standse trafikken, så andemor med ællinger kan komme sikkert over gaden, kan naive sjæle ledes til at tro, at samfundet er et fællesskab, der skal gøre det godt for alle mennesker, og at den politiske virksomhed har til opgave at gøre folk lykkelige. Sådan forholder det sig ikke. Opgaven for den politiske virksomhed er at finde veje og midler til at tæmme de befolkningsmæssige modsætninger, så de ikke bryder ud i vold. Dette sker blandt andet gennem den modernisering af velfærdsstaten, der implicit samordner finans-, social- og sundhedspolitikken. Sammenhængen mellem socialpolitikken, den fortsatte finansiering og opretholdelse af velfærdsstaten, folkesundhedsprogrammet og en overordnet optimering af samfundslegemet skulle nu være til at få øje på.

Med et eksempel fra programmet kan betragtningerne her konkretiseres. I 1995 var der godt 13.000 dødsfald, der kunne relateres til tobaksbrug, hvilket svarer til 178.000 tabte leveår, fordelt med ca. en tredjedel i hver af aldersgrupperne 35-59, 60-69 og 70- år. ${ }^{14}$ Med en grov forsimpling kunne man herefter se på, hvad disse tabte leveår svarer til i skattekroner. Vi må altså betragte de tabte leveår i forhold til gruppen under 67 år, altså den erhvervsaktive del af gruppen. Lavt sat drejer det sig i så fald om ca. 80.000 tabte leveår. Antager vi herefter løst sat, at en gennemsnitsindkomst er 286.692 kroner om året,,$^{15}$ svarer de tabte leveår til en mistet indtjening på 22,9 milliarder kroner, eller ca. 11,5 milliarder skattekroner om året. Og her var der vel at mærke kun tale om de tobaksrelaterede dødsfald. Der er, som det turde frem- gå, tale om et konstrueret eksempel, men det peger ikke desto mindre på nødvendigheden af at opretholde en arbejdsduelig befolkning som et vægtigt argument for en forøget forebyggende indsats. Folket skal kvitte smøgerne, dyrke mere motion og spise mindre fedt. Det skal trimmes og gøres fit for at sikre en stabil og effektiv arbejdskraft, som længst muligt er aktiv og dermed bidrager til velfærdssamfundets fortsatte eksistens, samtidig med at de offentlige udgifter, der er relateret til sygdom og for tidlig død, nedbringes. Dette bidrager også til forståelsen af folkesundhedsprogrammets fokusering på de midaldrende og på ønsket om etablering af en overordnet idræts- og motionspolitik. »Danskernes relativ lave middellevetid dækker ikke over den populære forestilling, at vi sparer et par år på plejehjem. Det er nemlig ikke de gamle, der dør tidligere. Det skyldes i høj grad, at mange tusinde midaldrende mænd og kvinder dør før pensionsalderen. ${ }^{16}$ Problemet angår således ikke pensionisterne. Om de dør som 75- eller 78årige er i denne sammenhæng ikke så interessant, nej miseren er netop, at det er samfundslegemets produktive celler, der mistes, og det skal ændres.

Trimningen af samfundslegemets celler, de enkelte individer, har således at gøre med en generel modernisering af velfærdsstaten, hvor folkesundhed identificeres med et sundt samfundslegeme. Men den sunde trimning indebærer nødvendigvis et $\varnothing$ nske om adfærdsregulering, der er forbundet med etablering og udbygning af en bestemt orden.

\section{Sundhed som orden}

Det er rimeligt - og erkendelsesmæssigt ganske frugtbart - at betragte sundhedsbegrebet som et begreb uden substans $\mathrm{i}$ 
egentlig forstand. Når begrebet er uden egentlig substans, ligger det til gengæld åbent for betydningstilskrivning af allehånde ide(ologi)er. ${ }^{17}$ Folkesundhedsprogrammet præsenterer den statsligt-officielle udlægning af sundheden. Programmets bagvedliggende mål indebærer et ønske om, at befolkningen indretter sig efter en bestemt hensigtsmæssig levevis, for at velfærdsstaten fortsat kan udvikles. Hermed kan folkesundhedsprogrammet betragtes som det nyeste udkast i en række af samfundsmæssige ordensprojekter med sundheden som omdrejningsfaktor. Der er dog ikke tale om noget epokegørende nyt, statsligt projekt. Igennem de sidste 200 år har sundhed været et vigtig begreb, når diskussionen har stået om reguleringen af samfundet.

Dette bekræftes, når ideologien bag folkesundhedsprogrammet konfronteres med det 18. århundredes befolkningsomsorg, som Johann Peter Frank står som den fremmeste eksponent for. I sit seksbinds værk om det medicinske politi, som omhandler alle sider af menneskets tilværelse fra byplanlægning, boliger, hygiejne, vandforsyning og kloakering til barnepleje og undervisning, gør Frank opmærksom på medicinens nødvendige ophøjelse til politisk og social videnskab. Således slås det fast, at:

»Statens sikkerhed er et anliggende for den generelle politividenskab. En meget betydelig del af denne videnskab består i at opstille principper i sundhedsomsorgen for folk, der lever i samfundet (...). Det medicinske politi er som al politividenskab en forsvarskunst, en beskyttelsesdoktrin for mennesker (...) imod de skadelige konsekvenser af at opholde sig sammen i stort antal, men især en doktrin for deres fysiske forbedring og velvære, således at folk så sent som muligt vil bukke under for deres skæbne på grund af de mange fysiske sygdomme, som de er udsat for. $\ll{ }^{18}$

Vor tid har i høj grad set opfyldelsen af Franks drømme. Medicinens rolle som socialpolitisk instrument er i dag mindst lige så stor, som da Frank skrev sit værk. Dengang var medicinens opgave at dæmme op for de skadelige virkninger af den $\emptyset$ gede urbanisering, som industrialiseringen bragte med sig. Den $\emptyset$ gede sammenstimlethed $\mathrm{i}$ byerne var skadelig for folk, hvorfor medicinen måtte mobiliseres $i$ forvaltningen af det sociale rum og dets cirkulationsformer - for eksempel ved epidemikontrol og karantænebestemmelser $\mathrm{i}$ forbindelse med pestudbrud. I dag består de skadelige virkninger ved urbaniseringens ændrede beboelsesformer ikke i risikoen for den hurtige epidemispredning. Nej, det skadelige findes i de muligheder, det civilisatoriske fremskridt har bragt det enkelte menneske vedrørende fysisk (in)aktivitet, føde- og nydelsesmidler. Men dengang som i dag består medicinens socialpolitiske opgave $\mathrm{i}$ at forbedre sundheden og forlænge levetiden $\mathrm{i}$ befolkningen.

I denne forbindelse er forebyggelse som medicinsk strategi væsentlig mere effektiv, end medicinsk behandling er det. Behandling vil altid være bundet til ét individ ad gangen, mens forebyggelsen er en strategi, der kan indbefatte hele befolkninger. Den forebyggende tanke har derfor vundet stadig større udbredelse i løbet af de seneste 30 år, men erkendelsen af forebyggelsens potentiale er ikke ny. Således har skabelse af orden via forebyggelse været en central del af de moderne staters udvikling. 
Forebyggelse og

\section{befolkningsomsorg $i$ det \\ 19. århundrede}

Selvom den europæiske modernisering og industrialisering forl $\varnothing \mathrm{b}$ meget usamtidigt, og England som det første land i verden erfarede hvad industrialiseringen førte med sig af dels velstand, dels massernes økonomiske og sociale forarmelse, kan man pege på en generel tendens til, at det absolutistiske ordensprojekt afvikles i perioden mellem slutningen af det 18. og midten af det 19. århundrede. Den nye statsformations ordensprojekt er i første omgang karakteriseret ved et modsætningsforhold mellem den politiske og den kapitalistisk- $\varnothing$ konomiske fornuft, idet $\varnothing$ konomien som orden er selvregulerende og derfor tenderer mod at afvikle den statslige forvaltning på dette område. På det sundhedspolitiske område viser dette velbekendte spændingsfelt sig tydeligt allerede i den moderne stats udgangspunkt, (nedenfor skal jeg vende tilbage til problemet, som det viser sig i dag). Selvom det medicinske politi i Franks version afvikles med det absolutistiske ordensprojekt, overtages dets funktion af de nye, sanitære reformbevægelser men nu uden den tætte forbindelse til staten. ${ }^{19}$ Den $\varnothing$ konomiske rationalitets liberalistiske laissez-faire doktrin, hvor reguleringen bestod af Adam Smiths 'usynlige hånd', havde sat sig igennem i politikken, hvilket nærmest bragte de sanitære reformbevægelser i opposition til statsmagten. Som den klassiske sundheds- og hygiejnestrategi appellerer disse nye, sanitære reformbevægelser til en politisk fornuft og overordnet styring på sundhedsområdet.

Grundlaget for de sanitære reformbevægelsers bestræbelser var ganske iøjnefaldende. En af de umiddelbart synlige effekter af industrialiseringen og den med- følgende voldsomme befolkningsforskydning, var en kaotisk urbanisering med befolkningskoncentration omkring de nye, industrielle produktionscentre. Friedrich Engels beretter i Conditions of the Working Man in England om den uorden, der florerer i disse storbyer. De er karakteriseret ved en forsumpende sammenblanding af mennesker, husdyr, affald, stinkende kloaker og latriner, hvis indhold sivede ud og blandede sig med den $\emptyset$ vrige søle, der skyldes mangel på dræning og brolægning af overfladerne. I denne sump lever »blege, slappe, smalbrystede og huløjede spøgelser $\ll^{20}$, der var gennemsyret af skrofulose og engelsk syge. 1830'ernes engelske proletariat var mennesker, der levede så langt som muligt fra den naturtilstand, som oplysningstidens filosoffer havde drømt om.

I begyndelsen bekymrede denne urbane uorden hverken stat eller borgerskab, men i længden kaldte den stadigt stigende uorden på regulativer og statslige initiativer. Erkendelsen af en nødvendig indgriben nås $\mathrm{i}$ det øjeblik, hvor forholdene bliver problematiske og faretruende også for stat og borgerskab. Der spreder sig en stigende frygt for revolutionære masseoptøjer, samtidig med at man indser, at den industrielle slum også er arnestedet for voldsomme sygdomsepidemier. Sygdommene truer ikke blot med at blive overført til de bedre kvarterer - og altså til borgerskabet selv men den høje dødelighed, den generelle elendighed $\mathrm{og} » . .$. den industrielle rovdrift på arbejdskraften truer også selve eksistensen af en arbejdsduelig befolkning «. ${ }^{21} \mathrm{Og}$ det er det egentligt bekymrende. Der er med andre ord brug for en helt ny type befolkningsomsorg. En ny orden.

Den praktiske konsekvens heraf blev parcelleringen af det urbane rum samt kontrol med dets cirkulationsformer. En stor del af de middelalderlige boligkvarterer 
blev saneret eller jævnet med jorden, der anlagdes gader og boulevarder, og der nedlagdes store, underjordiske kloakeringsnet. Den parisiske byplanlægger Georges-Eugène Hausmann, der ledede den sanitære omformning af Paris, sagde, at han havde skabt et »... alment kredsløbssystem, der på én og samme tid skulle gøre den urbane befolkning sundere og mindre tilbøjelig til opstand. ${ }^{22}$ At skabe sundhed og at skabe orden er identiske projekter, hvorfor det medicinske politi netop er en ordensmagt.

\section{Ordenstransformationen $i$ det 20. århundrede - en ny forebyggelse}

Mod slutningen af det 19. århundrede ændres billedet af hygiejne fra at have været en socialfilosofisk sundhedskategori til en teknik, fra en livskategori til en terapeutisk strategi. Denne transformation finder sted i kraft af en ny videnshorisont. I løbet af de sidste 100 år er videnskaben blevet i stand til at pege på den specifikke årsag til sygdom; fra omkring år 1900 kan årsagen i langt de fleste tilfælde identificeres og isoleres som levende dårligdom - altså bakterier og vira. Strategierne bliver herefter præcise og rettet direkte mod isolerede fænomener til forskel fra den socialfilosofiske bekymring for hele samfundslegemet, som kendetegnede både den absolutistiske stats medicinske politi og de hygiejniske reformbevægelser fra første halvdel af det 19. århundrede. Den videnskabelige succes, som læren om den specifikke ætiologi medførte, førte til troen på, at alle vigtige infektioner til sidst ville blive kontrolleret af terapeutiske sera og profylaktiske vacciner. $^{23}$

Det var denne holdning, der i det meste af det 20. århundrede gav lægevidenska- ben en enorm tiltro til egne evner. Sygdom ansås som havende en veldefineret årsag, og kontrol med sygdommen opnåede man bedst ved at angribe denne årsag eller sekundært ved at koncentrere behandlingen til den angrebne del af legemet. Hygiejnen havde hermed undergået en transformation fra social, filosofisk kategori til et teknisk, videnskabeligt begreb.

Men omkring 1960-1970 begynder medicinens udvikling at stagnere. Indtil da var apparaturet og behandlingerne blevet stadigt større, mere komplekse og mere omkostningstunge men uden egentlig nedgang $\mathrm{i}$ antallet af hospitalsindlæggelser og sygdom i befolkningen generelt. Årsagen er det ændrede sygdomsbillede. De sygdomme, der i dag dominerer, er sygdomme, som ikke har en specifik og udelukkende biologisk oprindelse. Det er sygdomme, hvis årsag i lige så høj grad skal søges i sociale og kulturelle forhold, og som derfor har en multifaktoriel ætiologi. Disse sygdomme lader sig ikke umiddelbart helbrede af en $\emptyset$ get farmakologisk indsats. Det samme gælder for en række kroniske, men ikke dødelige, sygdomme såsom allergi, astma, diabetes m.fl. Alle har de dog det til fælles, at de i vid udstrækning opfattes som noget, der kan forebygges. Det er således blevet vurderet, at op til 50 procent af alle dødsfald i dag skyldes livsstilsfaktorer, som kan ændres. ${ }^{24}$ Den umiddelbare mangel på muligheden for konkret medicinsk behandling af de nævnte sygdomme, samt muligheden for at forebygge dem, betyder dog ingenlunde, at behandling ad farmakologisk vej ikke tilstræbes. Der pågår i øjeblikket en intensiv forskning og et internationalt kapløb om udvikling af farmakologiske og genteknologiske præparater, der kan anvendes overfor civilisationssygdommene. Eksempelvis er Novo Nordisk i færd med at udvikle en 
fedmepille. Fremstilling og patentering af en sådan pille vil utvivlsomt medføre en enorm $\emptyset$ konomisk gevinst, og derfor er der betydelig markedsmæssig interesse i den sundhedsskadelige fedme. ${ }^{25}$ Dette forhold peger på det paradoks, at hvad der i én sammenhæng svækker samfundet gennem overbelastning af social- og sundhedsvæsenet, styrker det i en anden sammenhæng; nemlig forskningsmæssigt og $\varnothing$ konomisk. Omvendt vil en intensivering af forskningen, og eventuel efterfølgende markedsføring af en sådan pille, være i konflikt med og derfor føre til svækkelse af den førte sundhedspolitik. Hvilket dog ikke fører til politisk indgriben overfor den slags projekter. Det er $\varnothing$ konomien for vigtig og markedskræfterne for stærke til. Civilisationssygdommene og de medfølgende risici kan derfor langtfra kun udsættes for kritik og klage - de er samtidig en økonomisk vækstfaktor af første rang. Som blandt andre Ulrich Beck har påpeget, profiterer markedet og det industrielle system - og slet ikke så dårligt endda - af de misforhold som de, sammen med den $\emptyset$ vrige civilisatoriske udvikling, selv skaber. ${ }^{26}$ Markedskræfterne er på denne vis en vægtig modspiller til den førte sundhedspolitik, hvilket, som vi skal se nedenfor, er med til at give den et noget splidagtigt præg.

Men fra det statsligt-officielle synspunkt $m a ̊$ forebyggelsen, på grund af civilisationssygdommenes stigningstakt, (gen)introduceres som medicinsk strategi. Nok har forebyggelsen en lang historie bag sig, men den ordensstrategi, hvori den er et vigtigt led, ændres radikalt mod slutningen af det 20. århundrede.

Den medicinske teknologi udvikler sig stadig hastigt ikke mindst i kraft af den meget omtalte kortlægning af det menneskelige genom, men parallelt hermed er er- kendelsen af det umulige i at skabe orden, gennem forbedret teknologi og $\varnothing$ get medicinering, blevet dominerende. Derfor ændres strategien mod bevarelse af orden. Fornuften, som er bundet til terapien (af »therapeuein «; at pleje, behandle, kurere), erstattes i stigende grad af den profylaktiske fornuft (af »prophulaktein «; at våge over), der benytter sig af den noget mere defensive strategi forebyggelse. Det er bedre at sørge for, at noget ikke opstår, end at bekæmpe det når det er opstået.

Det er, som nævnt, de nye sygdomsmønstre, der er den afgørende tilskyndelse til at gå fra terapi til profylakse. Det er det, fordi disse sygdomme, udover deres komplekse ætiologi og dermed vanskeligere behandling, også er en konsekvens af måden, vi lever på. De er derfor blevet kaldt både livsstils- og civilisationssygdomme. Hermed antydes, at de er en omkostning eller nærmest en uomgængelig følgevirkning af at leve i det (post)moderne samfund. Sagt med andre ord er sygdom ikke længere en fremmed ondskab, en fjende i form af eksempelvis mikrober der invaderer os udefra, men som vi kan bekæmpe, når vi har opsporet dem; sygdom er blevet en risiko ved og i vores egen livsform. Noget som vi hele tiden selv skaber og udsætter os for men også må acceptere at leve med.

På grund af deres multifaktorielle ætiologi slår diagnosen for disse sygdomme over i en række modeller for sygdomsudvikling, der udgøres af samspillet mellem statistisk set risikofyldte faktorer. Diagnosen og behandlingen ændres hen imod en ny type forebyggelse, hvor det drejer sig om at kontrollere og undgå de samspil, som modellen peger på som risikable.

Den tydeligt identificerbare bevægelse i sundhedsprojektet $i$ det tyvende århundrede, fra omgivelser for smittefare til bekæmpelse af en bestemt livsstil, fører såle- 
des til en profylaktisk strategi, der i vidt omfang benytter sig af en risiko-moralisering, der retter sig mod snart sagt alle områder af livsførelsen. Som vi så det ovenfor, er det livsstilen, der er under anklage. En livsstil som er nært knyttet til identiteten. Sundhedsprojektet har altså bevæget sig fra et generelt samfundsmæssigt niveau til et subjektbundet, individuelt niveau. Det er nu de identitetsnære områder som mad, bevægelse, rygning og alkohol, der forsøges ændret på. Dette er tydeligvis et radikalt anderledes projekt. Hvor det $\mathrm{i}$ 1800-tallet drejede sig om bekæmpelse af smudset, urenhederne, mørket og den stillestående luft, drejer det sig nu om bekæmpelsen af rusen (alkoholen) og nydelsen (maden, smøgerne). Dette flytter fokus fra ændringer i befolkningens omgivelser over på den enkeltes krop. Skal sundhedsforeskrifterne følges, dømmes kroppen derfor til afsavn.

Udgangspunktet for den nuværende forebyggelsesstrategi er altså, at den enkelte har en krop, en biologisk krop, der er udsat for en uendelig række af risici, som kan forebygges ved hensigtsmæssig, rationel adfærd. Således består det (post)moderne ordensprojekt på den ene side af et moralsk projekt om risici på befolkningsniveau, som er institutionelt, videnskabeligt legitimeret, og på den anden side et internaliseringsprojekt, hvor de videnskabeligt beviste risici på befolkningsniveau - via begreber som ansvarlighed, skyld og skam - oversættes til handlingshenvisninger på individniveau.

\section{Skyld og ansvar - et paradoks i forebyggelsen}

Denne dobbelthed medfører et paradoksalt forhold til begreberne skyld og ansvarlighed. På den ene side tages det personlige ansvar i høj grad væk fra individet, på den anden $\emptyset$ ges ansvarligheden og ikke mindst skyldfølelsen i den enkelte.

Det første, fratagelsen af ansvaret, sker på to niveauer. Dels et overfladeniveau, der har at gøre med de konkrete forebyggelsestiltag, dels et dybere niveau, der har at gøre med selve forebyggelsestanken. Overfladeniveauet kan illustreres med debatten om rygning, der stod på henover sommeren og efteråret 2000. Med forslaget om indførsel af rygeforbud i en række offentlige institutioner, især på skolerne, ${ }^{27}$ signalerer man at såvel unge mennesker som de forældre, der har »svigtet deres ansvar«, ikke er i stand til at administrere deres eget liv og handlinger. Det offentlige må derfor sætte ind med regulativer og forbud for at tvinge en adfærdsændring igennem. CDs sundhedspolitiske ordfører, tidligere sundhedsminister Yvonne Herløv Andersen, mente i TVAs 'Synspunkt', at nu måtte det offentlige »tage ansvar« og indføre generelt rygeforbud de steder, hvor de unge færdes. ${ }^{28}$ Men for at det offentlige kan »tage ansvar«, skal det tage ansvaret for nogen. Nogen er i denne sammenhæng de unge, som ikke »har forstået budskabet « - de ryger ligeså meget i dag som tidligere. Debatten er et skoleeksempel på omsorgsvillen $^{29} \mathrm{i}$ aktion.

Det andet, dybere, niveau for afhænden af ansvar er integreret i selve måden, forebyggelsestanken manifesterer sig på. ${ }^{30}$ Den statistiske risiko for at blive ramt af en livsstilssygdom kan beregnes ud fra modeller, der inddrager de faktorer, der anses for relevante for en given sygdom. Tankegangen er herefter, at eftersom behandling ikke er »cost-benefit « effektiv, bør ressourcerne i stedet bruges til at sørge for, at sygdommene ikke opstår - dvs. kontrollere opkomsten og udviklingen af sygdom gennem eliminering af de uønskede adfærds- 
former. Risikomodellerne skal altså ligge til grund for en praktisk kontrol og ordning af vor adfærd med henblik på at undgå uorden. Skarpt trukket op indebærer logikken i den (post)moderne forebyggelsestanke en idealisering af det krise- og konfliktløse liv. Man gør et ideal ud af den perfekte orden for derved at kontrollere og forebygge mulig uorden. Tankegangen i denne statslige omsorgsvillen, med dens blik for alle tilværelsens lurende farer og faldgruber, bliver derfor formynderisk, ja tendentielt totalitær. Denne formynderiske omsorg for vor eksistens ender med at fratage det enkelte subjekt ansvar og indflydelse på eget liv. Den alkoholiserede, fede og rygende antimotionist er i denne optik ikke selv ansvarlig for sit valg af guldøl, grillmad, smøger og knallert-45 men offer for en række omstændigheder, og vi burde have identificeret ham som tilhørende en risikogruppe, inden det kom så vidt. Tænkt ud i sin konsekvens fører forebyggelsestanken derfor til en umyndiggørelse af borgerne og er dermed med til at fratage individet forestillingen om ansvarlighed for eget liv. ${ }^{31}$

Men som nævnt er der også en tendens til $\varnothing$ get skyldfølelse. Denne følelse hænger sammen med det (post)moderne tilværelsesperspektiv, hvor det primære er at holde sig i live - ilivelsesperspektivet er det med en neologisme blevet kaldt. ${ }^{32}$ Ilivelsesperspektivet står i nær relation til det forhold, at stadig større dele af tilværelsen i dag er blevet medikaliseret. Denne erfaring har ikke kun at gøre med det stadigt stigende antal opgaver, som sundhedsvæsenet tager sig af men er primært af bevidsthedsmæssig karakter. Siden midten af det 20. århundrede har sundheden gennemgået en enorm betydningsopskrivning. Det er ikke den medicinsk videnskabelige sundhed, der har været central her men sundheden som erstatning for det sande, »det videnskabeligt rigtige«, som idéhistorikeren Lars Henrik Schmidt har formuleret det. ${ }^{33}$ Dermed er referencen for sundhed ikke længere sygdom men usundhed. Det bliver overskridelsen af orden, provokationen af orden, der kommer i fokus. Konsekvensen er, at selv om vi ikke går rundt og reflekterer over det begrebsmæssige indhold af sundhedsbegrebet, sættes en lang række af vore hverdagslige handlinger ind i en sundhedsmæssig kontekst. Hvilket i praksis vil sige, at de sættes i en moralsk kontekst, idet det sunde nu jævnføres med den sunde fornuft. Pointen er dog, at sundheden selv herved uselvfølgeliggфres. Billedet herpå er joggeren, der overvåger sig selv konstant skelende til pulsuret. Her er sundheden ikke længere givet a priori. ${ }^{34} \mathrm{Et}$ sådant billede peger på en opfattelse af sundhed som noget, der konstant skal gives opmærksomhed for ikke at fortabes. Hermed er der åbnet for et nyt synderegister og nye måder at få syndernes forladelse på. Har vi syndet ved at spise en flødekage til kaffen, må vi huske senere at løbe bodsturen rundt om søen eller tage en ekstra portion råkost til aftensmaden. ${ }^{35}$ Vi noterer hele tiden vore livshandlinger i sundhedens store regnskabsbog. Har vi trukket over, må vi senere huske at sætte ind. Sundhedsregnskabet skal stemme. Det er blevet integreret i os. Overvågningen af sundheden, som på Franks tid skulle foretages af et konkret, medicinsk politi, er i dag blevet intrinsisk, den er ved at blive installeret i det enkelte subjekt som selvovervågning. Hygiejnen er hermed vendt tilbage til det medicinske politi, og ringen er sluttet. Blot er monitoreringen blevet til selvmonitorering, en overvågnings- og disciplineringsform som i virkeligheden er langt mere effektiv, end den Franks medicinske politi ville kunne gennemføre. Der har i den gode samfunds- 
borger udviklet sig en radikal version af det, den engelske filosof Jeremy Bentham i 1791 præsenterede som »Panopticon - or the Inspection House«. Panoptikonet (sammensat fra græsk af »pan(to)«; præfiks der angiver, at noget er altomfattende, og »optikos «; angående synet) er det sted, hvorfra alt kan ses eller overvåges. Hos Bentham var det oprindeligt en arkitektonisk konstruktion bestående af et tolvsidet polygon med et centralt tårn, hvorfra en myndighed kunne overvåge adfærden hos institutionens beboere/indsatte/patienter. Men Bentham kom til at betragte panopticisme som et sæt af principper, der kunne bruges til alle former for social styring. Fængslet var blot den mest simple institution, principperne kunne overføres på. Det er derfor, den franske filosof og idéhistoriker Michel Foucault i sit værk Overvågning og straf kan beskrive, hvordan fængslerne på denne måde kommer til at danne grundformen for samfundets $\varnothing$ vrige institutioner ved at afspejle fabrikker, skoler, kaserner og hospitaler, som alle igen afspejler fængsler. ${ }^{36}$ Panoptikonet bliver hermed modernitetens arkitektoniske udtryk for 'viljen til magt', idet det kan transformere overvågning til selvovervågning. Med (selv)overvågningen reformeres individets karakter. Heri består panoptikonets genialitet.

Panopticismen medfører, at en bestemt moral, et bestemt kodeks for adfærd, overføres fra den, der overvåger, til den, der overvåges. Det er derfor, Foucault med Nietzsche kan sige, at moralen er et magtmiddel til disciplinering. Internaliseringen af bestemte magtstrukturer kommer således til at virke adfærdsregulerende. I vort tilfælde sørger det symbolske panoptikon, i form af den latente men konstante skyldf $\varnothing$ lelse, for at holde orden i sundhedsregnskabet.

Samtidig kan vi konstatere, at koblingen mellem moral, synd og nydelsesmidler i dag er så velbekendt, at man bevidst kan spille på temaet, når et produkt skal markedsføres. Man kan appellere direkte til synderen i os alle. Dette ses eksempelvis i den kampagne Danske Slagterier ('Danepak') kørte i efteråret 1999 for deres forstegte bacon, som sælges i de engelske supermarkeder. Sloganet, der skulle få folk til at spise produktet som snack, lød: »Go on, be a devil! «. Og det var ledsaget af en smilende rød lille djævel med horn og trefork som kampagnens gennemgående figur. Ved at spise baconet, som er »wickedly delicious «, bryder vi, i en syndig pagt med djævelen, med sundhedsreligionen. Djævlen frister, og vi lader os friste.

En tilsvarende leg med synds- og fortabelsessymbolerne ses i flere af biografernes spiritusreklamer. Spiritus kan (såvel som spil og sex) føre til ekstase og derved til tab af den rationelle kropslige kontrol (græsk: »ekstasis«; bortrykkelse, at være ude af ligevægt, 'ude af sig selv'). Hvordan der kan spilles på dette forhold er en af reklamefilmene for Bacardi Rom et fremtrædende eksempel på. ${ }^{37}$ Lokationen, hvor handlingen udspiller sig, er det dampende hede Santiago de Cuba, året 1938. Hovedpersonen sidder optaget af spil, mens han indtager Bacardi Rom i stor stil. Samtidig er han i stand til at flirte med, og efterfølgende score, barens flotteste pige, som han har sex med. Efter denne tredobbelte synd (spil, spiritus og sex) vågner han op fra ekstasen med Bacardis djævlelignende flagermusebillede tatoveret på armen. Synden fører ganske givet til ekstasen men også til fortabelsen i form af den stigmatiserede alliance med det onde. Vi ved det ligeså vel som forebyggelsesrådet. Alligevel falder vi momentant for fristelsen og flirter med synden og det onde. Hermed er det også tydeliggjort, at den syndige usundhed 
mere er et socialt end et medicinsk problem.

På denne baggrund er det rimeligt at hævde, at sundhedsfremmen »egentlig blot (er) en ny variant af moralens genealogi; formålet med denne foranstaltning er nu som før at kunne ford $\phi m m e$ en adfærd « ${ }^{38}$, som Lars Henrik Schmidt pointerer. Sundheden bliver lagt til grund for moralske domfældelser, hvilket tydeligt manifesterer sig i både diskussionen om rygning samt hele den ophedede dopingdebat. ${ }^{39}$ Sundheden er på én gang det mest kollektive og det mest individuelle. Derfor opfattes det nærmest som kætteri, hvis nogen vælger bevidst at blæse på sundheden.

Men som vi så det ovenfor med baconog Bacardi-eksemplerne, så bliver der blæst på sundheden. Hos de fleste er der tale om et forbigående pust af umoral og syndighed, som, for en ordens skyld, atter afløses af bodsøvelser og selvovervågning, når tømmermændene melder sig. Men hos andre er den moderne panopticisme slet ikke, eller kun minimalt, installeret. De afviser med andre ord den moralske adfærdsregulering, der ligger i panopticismen. De fleste kender eksemplet med den fede, der sidder på grillen og spiser burgermad. Hans nærmest bevidst syndige adfærd rammer os som en storm af moralsk overdrivelse. Mennesker som ham har ikke forstået den nye, rationelle enhed af det sunde og det sande, hvorfor deres overskridende adfærd, i form af en mangel på (kropslig) selvbegrænsning, er en provokation mod det ordentlige, og som sådant viser det hen til det irrationelle og dermed onde. Panoptikonets moralske adfærdsregulering virker bedst på dem, der ikke tror på panoptikonet, dem der selv vil det, der opfattes som optimalt for samfundslegemet.

På det folkeligt-individuelle niveau for sundheden er heterogeniteten således sta- dig fremtrædende. At de nævnte overskridelser endnu ikke er fuldstændigt eksorciseret fortæller os, at selvom vort liv finder sted i et sekulariseret, moderne, ordentligt og gennemrationaliseret samfund, er mennesket og livet selv umoderne og ikke så rationelt, som vi gerne gør det til. ${ }^{40}$ Panopticismen er netop et udpræget moderne fænomen udsprunget af oplysningstidens tiltro til det fornuftige, oplyste menneske og det rationelle fremskridt. Folkesundhedsprogrammet bygger i høj grad på samme type af rationel oplysningsfilosofi, hvorfor panopticismen kommer til udtryk som et uofficielt statsligt styringsredskab af den individuelle og dermed den kollektive sundhed.

Med en sådan erkendelse kan vi nu få $\varnothing j \mathrm{j}$ på årsagen til paradokset med folkesundhedsprogrammets samtidige fratagelse og forøgelse af det individuelle ansvar. Dobbeltheden udspringer af den 'sundhedsopdragende' magtstrategi, der netop sætter sig igennem som en individualisering af det kollektive ansvar. I erkendelsen af, at en forbedring af danskernes middellevetid kun kan ske gennem forbedring af den enkeltes sundhed, må bekymringen for middellevetiden nødvendigvis tage form af en ansvarliggørelse af den personlige sundhed.

I folkesundhedsprogrammet udtrykkes denne strategi således: »At forbedre folkesundheden kræver ændrede adfærdsmønstre men ikke nødvendigvis voldsomme ændringer - set fra den enkeltes synspunkt. Små ændringer, udført af mange, giver store resultater. $\ll^{41}$ Den enkelte kan altså deltage i det kollektive ansvar ved blot minimalt at forbedre egen sundhed. En kollektiv forbedring vil vise sig, praktisk talt uden at den enkelte mærker forbedring af sin individuelle sundhed. Man kan godt fravælge sundheden. Men ved på denne vis 
ikke at bidrage til samfundslegemets sundhed, ekskluderer man sig selv fra en del af det sociale felt. Man opfører sig asocialt, idet man ikke yder sit bidrag til folkesundheden. At den fede fordømmes er konsekvensen heraf.

\section{En sundheds- og idratspolitik $i$ splid med sig selv}

Lad os afslutningsvist se på to af folkesundhedsprogrammets væsentligste tiltag: indsatsen mod rygning og intentionen om iværksættelse af en egentlig idrætspolitik.

Rygning er farligt. Rygning dræber. Hver syvende storryger udvikler lungekræft. Historien er kendt, og der hersker bred folkelig opbakning omkring den hårde kurs overfor rygerne. Der er forståelse for, at det er en god idé at brandbeskatte cigaretter. Får det ikke rygeren til at kvitte smøgerne, har vedkommende i det mindste selv bidraget væsentligt til finansieringen af sin egen indlæggelse, når den tid kommer. Det giver ganske vist anledning til debat, når stadig flere offentlige og private bygninger og institutioner gøres røgfri. Men der er øjensynligt en bred accept af den slags beslutninger på trods af rygernes protester mod indgrebene i deres personlige frihed. Men er det overhovedet rimeligt at tale om frihed i deres situation? Aktuelt er det som om rygerne betragtes som slaver af cigaretterne, ${ }^{42}$ som ofre for den tobaksindustri der i realiteten er ondets rod. Når tobakskompagnierne nu slæbes i retten, er det en konsekvens af perspektivskiftet fra rygeren som fri og myndig borger til umyndigt offer for en afhængighedsskabende industri. ${ }^{43}$

Men det er ikke kun tobaksindustrien, der trækker veksler på sundheden. Mange andre ting truer danskernes sundhed. Biler- ne er for eksempel en helt konkret risiko. Der er stor fare forbundet med at bevæge sig ud i trafikken, hvor vi ufrivilligt må inhalere bilernes udstødningsgasser, og hvor både børn og voksne helt konkret slås ihjel. Også bilisten selv er i fare, fordi han netop ikke bevæger sig i trafikken. Han sidder i stedet stille og får derfor ikke den helsebringende motion, der kan modvirke fedme. Bilisten har således forøget risiko for åreforkalkning, hjerte-kar sygdomme, forhøjet blodtryk og ditto plasmakolesterol. Han risikerer at blive ramt af diabetes, få knogleskørhed og tyktarmskræft. Der kan ikke herske tvivl om bilernes skadelige indvirken på vores sundhedstilstand og dermed på folkesundheden. Derfor ville det gavne sundheden at adskille biler og mennesker, på samme vis som man i 1800tallet med de store kloakeringsarbejder adskilte lort og mennesker fra hinanden, eftersom dette samkvem var skyld i de store infektionssygdomme. Adskillelsen gav et renere og sundere menneske. En sådan adskillelse står dog ikke lige for, og i modsætning til antallet af rygere kommer der stadig flere biler og bilister. Den førte politik synes på ingen måde at lægge en dæmper på privatbilismen. For en ideel betragtning synes det ellers ikke at være så vanskeligt. Byernes centre kunne gøres forbudt for biler. Biler og brændstof kunne beskattes væsentligt hårdere, og bilreklamer kunne forbydes eller i det mindste forsynes med lovpåbudte advarselsskilte, hvor bilismens sundhedsskadelige virkninger blev fremhævet med fede typer. »Biler dræber!«. »Biler er årsag til kræft!«. Det sker imidlertid ikke, og det er der gode grunde til. Når rygerne har måttet underlægge sig sådanne indgreb, samtidig med at de kan konstatere, at bilisterne ikke udsættes for det samme, skyldes det at den menneskelige sundhed er underordnet et 
andet hensyn. Nemlig hensynet til samfundsøkonomien, hvis sundhedstilstand i realiteten identificeres med samfundslegemets. Samfunds $\varnothing$ konomien er afhængig af markedet som i vid udstrækning er blevet selvstyrende og automobilt. Bilerne er måske det mest iøjnefaldende, men eksemplerne er legio. ${ }^{44}$

På samme vis som det gjaldt for udviklingen af fedmepillen, er de $\varnothing$ konomiske og markedsmæssige interesser ofte vigtigere end de sundhedsmæssige. Når tobaksindustrien til trods herfor for indeværende er underlagt kraftig kritik, er det i højere grad udtryk for $\varnothing$ nsket om at finde en syndebuk, end det peger på viljen til at løse sundhedsmæssige problemer på individniveau. En industri ofres, for at de andre kan leve. ${ }^{45}$

Ovenstående peger på et generelt sundhedsmæssigt kursskifte, der aktivt kommer til at involvere idrætten. Kursskiftet er en konsekvens af det, den engelske sociolog Anthony Giddens har betegnet som vort ridt på »Jagannathvognen $\ll{ }^{46}$ Som billede på moderniteten udgør Jagannathvognen ...

$\gg$... en løbsk maskine med en enorm kraft, som vi - kollektivt som mennesker $-i$ en vis udstrækning er i stand til at styre, men som også truer med at sætte sig ud over vores kontrol og splitte sig selv ad. Jagannath knuser dem, der modsætter sig den, og selv om den indimellem ser ud til at være på ret kurs, drejer den på andre tidspunkter uberegneligt væk i retninger, der ikke er til at forudse. (...) Så længe modernitetens institutioner består, vil vi imidlertid aldrig være $\mathrm{i}$ stand til fuldstændigt at kontrollere turens retning eller fart. $\ll^{47}$

Billedet indebærer netop skiftet fra offensive styrings- og planlægningsstrategier til defensive tilpasningsstrategier. Der er ikke tale om, at vi lever i et ukontrollerbart samfund, men en erkendelse af at vore styringsredskaber i høj grad er bundet op på, og $\mathrm{i}$ en vis udstrækning underlagt, markedskræfterne. Med andre ord: markedet er blevet samfundsmæssighedens primat. Dette er en væsentlig årsag til skiftet fra en offensiv til en defensiv sundhedsstrategi. Når det i folkesundhedsprogrammet således proklameres, at der er behov for at formulere en central motionspolitik »... så områdets store betydning for folkesundheden både styrkes og synliggøres «, sker det som et led i en afmagtsstrategi. Idræt er blevet den medicin eller terapi, som er midlet til at pansre og livsforsikre befolkningen fra risikofyldte omgivelser, som statsmagten ikke længere er i stand til at kontrollere gennem planlægning. Den annoncerede motionspolitik eksemplificerer med sine mål denne defensive afmagtsstrategi. Dels skal den »... tilskynde den voksne befolkning til at dyrke den halve times anbefalede motion dagligt«, dels gennem byplanlægning sørge for at $» . .$. større og lettere adgang til fritidsarealer, cykelstier m.v. medvirker til at styrke motionsområdet. $\ll^{48}$ Den første anbefaling bygger på internationale epidemiologiske studier, der har kortlagt sammenhængen mellem motion og en række sygdomme, primært hjertekar sygdommene. ${ }^{49}$ Den anden kan tages som udtryk for vor tids defensive forlængelse af det 19. århundredes offensive bestræbelser for at kontrollere det urbane rums sygdomsfarer. Dengang gennemførtes de store sanerings- og kloakeringsarbejder for at kontrollere smittespredningen, i dag bygges cykelstier og fritidsarealer for at styrke og fremme en hensigtsmæssig livsstil.

Et prægnant udtryk for denne vilje til omsorg og sikring af befolkningens sundhed gennem idræt findes $\mathrm{i}$ de offentligt 
støttede kampagner for idræt på arbejdspladsen. Når sådanne sundhedsfremmende aktiviteter mobiliseres, er det uomtvisteligt bl.a. af hensyn til samfunds $\varnothing$ konomien, idet der, som vist, er en snæver forbindelse mellem sundhed og økonomi i statsligt regi. Pjecen På vej mod en sundere arbejdsplads - fokus på motion ${ }^{50}$ er et karakteristisk eksempel på en sådan omsorgsvillen $\mathrm{i}$ aktion. Den indledende overskrift $\gg$ Fælles indsats - fælles udbytte « giver os fra starten indtrykket, at idræt på arbejdspladsen er en givtig investering for virksomheden og ikke kun et tiltag, der er tænkt til fremme af medarbejdernes sundhed og trivsel. Dette indtryk bekræftes i en oversigt, der fortæller om både medarbejderen og arbejdspladsens fordele ved tiltaget. Her hedder det bl.a., at motion på arbejdspladsen fører til »forebyggelse af arbejdsskader og færre sygedage«, og at »... arbejdspladsens image styrkes både internt og eksternt.« Logikken er, at dette kan medføre større indsats på arbejdspladsen og dermed større rentabilitet, for, som det hedder, »Godt arbejdsmiljø er i stigende grad en lønsomhedsfaktor, der stimulerer til indsats og reducerer risikoen for uheld, nedslidning og sygdom. $\ll^{51}$ Forhold der naturligvis er med til at $\varnothing \mathrm{ge}$ virksomhedens markedsværdi og dermed dens mulighed for afkast. Uanset at ideen er båret af de bedste intentioner, er det tydeligt, at politikken bagved står med et noget ambivalent motiv. Den intenderer i sin omsorgsvillen at være offensiv og livskvalitetsforbedrende for den enkelte men er netop indrettet efter, hvad der fra en bestemt position forekommer nyttigt. Fra det statsligtofficielle synspunkt er det nyttigt, at den enkelte borger integrerer fysisk aktivitet med moderat intensitet i sin hverdag. Dels til sundhedsmæssig pansring, dels til styrkelse af hans produktions- og markedsvær- di og dermed til samlet forbedring af samfundslegemets sundhed. At det er velfærdsstatens overlevelse, der står på spil, synes også her at skinne igennem. Vi opfordres netop ikke til at jage rundt med tungen ud af halsen, men blot at indpasse fysisk aktivitet med moderat intensitet $\mathrm{i}$ vor daglige tilværelse, ${ }^{52}$ det er på alle måder det sikreste og bedste.

Det er nemlig almindelig (folke)visdom, at overdreven fysisk udfoldelse bestemt ikke er sundt. Således vendes der i TVs debatudsendelser om sport med jævne mellemrum tilbage til det sundhedsmæssigt problematiske i at leve som elitesportsfolk, der træner 15-25 timer ugentligt, gør. Helt i tråd hermed er det en del af den annoncerede motionspolitik, at »De sundhedsskadelige forhold i idrætskulturen skal reduceres og forebygges, herunder især idrætsskader og doping. ${ }^{43}$ Forhold der, skal man fæste lid til sportsmedierne, er en integreret del af elitesporten. En politik, der vil fremme sundheden gennem anbefalinger om mere fysisk aktivitet med moderat intensitet, ville derfor fremstå som inkonsekvent, hvis den samtidig førte en politik til fremme af eliteidrætten. Det har man ikke desto mindre gjort systematisk, siden man i 1984 under kulturministeriet oprettede Team Danmark. Organisationen til fremme af eliteidræt har et årligt budget på ca. 115 millioner kroner, hvoraf de 67,2 millioner kommer direkte fra kulturministeriet (1999tal), og yderligere 18,8 millioner modtages fra Danmarks Idræts Forbund..$^{54} \mathrm{I}$ alt altså 86 millioner kroner fra tips- og lottomidlerne. Af disse går 65,5 millioner som forbundsstøtte direkte til udøverne. ${ }^{55}$

Da man tilbage i 1976 begyndte at debattere eliteidrætten i folketinget, var der ikke synderligt stor interesse $\mathrm{i}$ en direkte støtte hertil. Peter Brixtofte udtalte dengang, at »... efter Venstres opfattelse er det 
ikke en statsopgave at dyrke eliten. ${ }^{56} \mathrm{I}$ løbet af de næste otte år ændrede partiet dog opfattelse, således at Helge Sander i 1984, da man vedtog lov, om fremme af eliteidræt, kunne opfordre til støtte af eliten. Udover behovet for tilskueroplevelser fremhævede han eliteidrættens propagandaværdi til eksportfremmende aktiviteter »... på lige fod med medlemmer af kongehuset og ministre. $\ll{ }^{57}$ Hverken elitesportens fascinations- eller markedsværdi er mindsket siden 1984. På denne vis er selv »den mest vidtdrevne eliteidræt (...) i mindst to henseender at regne for sund. Dels derved at den formår at aktivere og interessere mennesker. Dels netop i samfundsøkonomisk betydning for så vidt den formår at skabe resultater, som vinder genklang på eksportmarkederne. $\ll^{58}$

Det tegner tilsammen billedet af et politisk janushoved, der i sin omsorgsvillen med den ene mund anbefaler sundhedsfremmende, moderat, fysisk aktivitet og med den anden støtter en $\gg$ socialt forsvarlig « eliteidræt, til trods for at den måtte være helbredsskadelig.

Dette er endnu et eksempel på, at markedets interesser og $\varnothing$ konomien er vigtigere end de individuelle udøvernes sundhed. Bag diverse rationaler for en statslig finansiering af eliten ligger den antikke forestilling om, at nogle få individer må ofres til fordel for arten. Sagt med andre ord: hvor sundheden i andre sammenhænge udgør et vægtigt argument for indgreb og regulering (samt retten til moralsk fordømmelse), så opløses dette argument, når det står overfor større markedsmæssige interesser, end det selv kan tilbyde. Netop dette er med til at give sundhedspolitikken sine ambivalente træk. Træk der henleder vor opmærksomhed på den påstand, vi fremsatte ovenfor, nemlig at sundhedsbegrebet er et tomt begreb uden egentlig substans, hvorfor det netop er egnet til udfyldelse af skiftende ideologiske formål af ovenstående slags.

\section{Afrundende}

Sundhedsprojektet er et tragisk projekt. Tragisk i den forstand at det er uafslutteligt. Problemet er ikke så meget, at vi har et ideal om sundheden, mere at vi tror, det kan og skal realiseres. Sundheden er nemlig ikke et højeste gode, et optimum, men noget man måske kan optimere. Alligevel opfattes sundheden som et sådant højeste gode, der på en gang er så selvfølgeligt, at der ikke spørges til dets autoritet som selvstændigt argument, samtidig med at jagten på evig sundhed har gjort den uselvfølgelig. Den er ikke længere blot den naturlige baggrund, som sygdom optræder på, men noget der konstant skal gives opmærksomhed for ikke at fortabes.

Denne dobbelthed fører aktuelt til på den ene side $\varnothing$ nsket om mere sundhed gennem en officiel idræts- og motionspolitik og anbefalinger om en daglig halv times fysisk aktivitet med moderat intensitet, på den anden side en intensiv indsats mod den fede $\operatorname{mad}^{59}$ men især mod rygere og tobaksindustri. Omsorgen for danskernes sundhed er i begge tilfælde det udslagsgivende argument. Men parallelt hermed synes sundhedsargumentet at udspille sin rolle, når det kommer til problemer, der involverer de markedsmekanismer, der er mere påtrængende end sundheden selv.

Dette synes paradoksalt, al den stund det meget ambitiøse folkesundhedsprogram som mål har at forlænge danskernes middellevetid og mindske uligheden i sundhed. Omvendt svarer intentionerne bag programmet godt til den politiske kontekst, det er udsprunget af. Den fortsatte opretholdelse og finansiering af velfærdsstaten 
nødvendiggør en modernisering og trimning af samfundslegemet og dermed legemets celler - de enkelte individer. Når livsstilsbegrebet i denne henseende er blevet centralt for den forebyggende indsats, på trods af at det er en åbenlys konstruktion, skyldes det nødvendigheden af at operere på et strukturelt plan, når samfundslegemets sundhed skal forbedres. På denne vis bliver folkesundhedsprogrammet en del af et samfundsmæssigt ordensprojekt, hvor overvågning efterhånden er blevet til selvovervågning reguleret af den sunde fornuft. Hermed er det også sandsynliggjort, at sundhedsprojektet mere er et moralsk end et medicinsk projekt, en del af en moralens genealogi og som sådan velegnet som redskab til fordømmelse. En fordømmelse der aktuelt manifesterer sig overfor rygere og tobaksindustri, men som går andre industrier forbi, idet det viser sig i højere grad at være samfunds $\varnothing$ konomien, og dermed samfundslegemet, end individernes sundhed, der reelt er i fokus. Den aktuelle sundhedspolitik, med dens annoncerede motionspolitik, viser sig således at være særdeles ambivalent. Der er tale om en ordens- og opdragelsesstrategi, der $\emptyset n$ sker en defensiv adfærdsregulering for at sikre og pansre sundheden mod de af det (post)moderne samfunds farer, som politikken ikke længere offensivt er i stand til at kontrollere.

\section{Noter}

1. Nærværende artikel er et uddrag af mit speciale ved Institut for Idræt og Biomekanik, Syddansk Universitet, Odense, december 2000.

2. Sundhedsminister Carsten Koch i Politiken den 1. august 1999.

3. Det filosofiske og det sociologiske har ikke nødvendigvis samme rækkevidde eller genstandsfelt. Som filosofisk almenhed ville programmet sigte til alle og enhver, det ville gælde universelt (for danskerne), mens den sociologiske fælleshed ville sigte mod samtlige af det afgrænsede, sociale fællesskabs medlemmer.

4. Møller (1997), s.: 18-105.

5. Regeringens folkesundhedsprogram 1999, s. 7.

6. Regeringens folkesundhedsprogram 1999, s. 47.

7. På side 12 i programmet står der: »Folkesundheden skal forbedres, og den sociale ulighed i sundhed skal formindskes væsentligt. Disse to mål er programmets overordnede mål.« (Min kursivering). Altså, hvor målsætning 1 andre steder i programmet formuleres: »Middellevetiden skal forbedres, og ... «, er ordet middellevetid her erstattet af ordet folkesundhed. De to begreber opfattes som synonyme.

8. Danmark har igennem de sidste 30 år har haft den ringeste udvikling i middellevetiden sammenlignet med de $\varnothing$ vrige EU-lande. Fra at danske mænd

i 1970 lå som nummer fire blandt de nuværende 15 EU lande og Norge, og danske kvinder lå som nummer fem, er Danmarks placering i 1996 ændret til nummer 15 for mænd og nummer 16 for kvinder.

9. I forhold til programmets overordnede mål om en forbedring af danskernes middellevetid, vurderes det, at en reduktion $i$ andelen af rygere $i$ alle aldersgrupper udløser den sikreste og kvantitativt mest afgørende effekt på sygelighed og dødelighed i programperioden. Ved hjælp af en ny matematisk model, preventmodellen, som kan beregne, hvad ændringer i sundhedsadfærd og livsstil betyder for dødeligheden og middellevetiden, har man undersøgt, hvordan udviklingen i middellevetiden vil blive, hvis andelen af cigaretrygere gradvist går ned med en tredjedel i løbet af en tiårig periode. For tobakssygdomme som lungekræft, rygerlunger, iskæmisk hjertesygdom og apopleksi viste modelberegningen at det om ti år vil give en længere middellevetid for mænd på ca. 2,5 måneder og for kvinder på ca. 1,5 måned. De fire nævnte sygdomme gør det imidlertid kun ud for ca. halvdelen af alle rygerrelaterede dødsfald, hvorfor man i runde tal kan anslå, at man over ti år vil kunne vinde mellem 3 og 6 måneder i den gennemsnitlige middellevetid. (Regeringens folke- 
sundhedsprogram 1999-2008, s. 31.). En sådan stigning i middellevetiden ville bringe danske mænd op på en 12. plads i den nuvarende oversigt, hvilket svarer til Irlands placering. For danske kvinders vedkommende ville forbedringen ikke betyde noget for deres 16. plads i tabellen. Danskernes rygevaner kan således ikke alene forklare den dårlige middellevetid. Så er der de andre forklaringsfors $\emptyset \mathrm{g}$, som for eksempel det faktum at danskerne drikker meget $-i$ hvert fald mere end nordmænd og svenskere gør. På den anden side drikker danskerne en hel del mindre alkohol end franskmændene, der trods det lever længere end danskerne. Heller ikke et dårligere sundhedsvæsen kan alene forklare miseren. WHO placerede i en rapport fra sommeren 2000 det danske sundhedsvæsen på en 34. plads i verden. Dette kunne hænge sammen med, at der i Danmark bruges færre penge på sundhedsvæsenet end i de lande, vi normalt sammenligner os med. Men om dette har betydning for behandlingskvaliteten er vanskeligere at vurdere. Man har fors $\emptyset \mathrm{gt}$ at opregne de dødsfald, der kunne være undgået, hvis korrekt behandling havde været foretaget. Det ligger i Danmark på ca. 5000 dødsfald årligt, hvilket er lidt højere end i de øvrige nordiske lande (men bedre end det europæiske gennemsnit). Danske kræftpatienters overlevelse fem år efter behandlingen af de hyppigst forekommende kræftformer er 10 procent ringere end i de $\varnothing$ vrige nordiske lande. Disse tal bekræfter den generelle konklusion fra WHO-rapporten fra juni 2000 - det danske sundhedsvæsen ligger lidt under det europæiske gennemsnit. Omvendt viser beregninger, at en 10 procent forøgelse af bevillingerne til sundhedsvæsenet blot ville $\varnothing$ ge middellevetiden med mellem 0,06\% og 0,20\% (Mørch (1996), s. 443), og konklusionen må derfor blive, at selvom det danske sundhedsvæsen nok ikke er verdens bedste, så er det ikke så meget ringere end i andre lande, at det er værd at bruge mange penge på at rette det op.

10. Om man betragter Newtons fysik, de Lavoisiers kemi eller Pasteurs medicin, så er de videnskabelige landevindinger nået gennem parcellering og differentiering af de respektive felter. Videnskaben søger således, i modsætning til mysticisme og okkultisme, at komme til forståelse af sit felt gennem en rationel skillen ad i dele, der gør det muligt at fremsætte hypoteser, som efterfølgende forsøges verificeret eller, endnu bedre, falsificeret. Gode hypoteser kan senere danne grundlag for gode teorier, der igen danner grundlag for forkla- ringer og forudsigelser. Derimod udgør et felt der ikke lader sig skille ad i dele en dårlig videnskabelig teori, idet den ikke, eller kun vanskeligt, er mulig at falsificere.

11. Verner Møller har differentieret mellem tre funktionsniveauer for sundhedsbegrebet, der bygger på den efterhånden klassiske, trialektiske tankefigur om stat, marked og civilt samfund. De tre funktionsniveauer, der netop er ganske nyttige i en analytisk sammenhæng som nærværende, er det statsligt-officielle niveau, det privat-ideologiske niveau og det folkeligt-individuelle niveau. Møller (1999), s. 96 ff.

12. Roger Qvarsell har anført, hvordan drømmen om sundhed, ofte også er en drøm om lykke. Se Qvarsell (1989).

13. Månson (2000), samt Mørch (1996), 49. fortælling.

14. Regeringens folkesundhedsprogram 1999, s. 21.

15. Dette beløb udgør en gennemsnitsindkomst i den private sektor i Ringkøbing Amt i 1998 og er inklusiv elever og unge under 18 år. Oplysningerne er hentet fra Danmarks Statistik.

16. Regeringens folkesundhedsprogram 1999, forordet.

17. Møller (1999), s. 77.

18. J. P. Frank, System einer vollständigen medicinischen Polizey, Mannheim, 1779 - 1817, I - VI. Her citeret efter Schmidt og Kristensen (1986), s. $31 \mathrm{f}$.

19. Schmidt og Kristensen (1986), s. 25-49.

20. Citeret fra Dubos (1960), s. 115.

21. Schmidt og Kristensen (1986), s. 37 f.

22. Citeret efter Schmidt og Kristensen (1986), s. 46.

23. Dubos (1960), s. 118.

24. Elsass (1993), s. 448.

25. I den seriøse ende af fedmeindustrien finder vi behandlingen af diabetes som er en af de hyppigste følgesygdomme fra overvægt og fedme. Novo Nordisk er en af Europas største producenter af den for diabetikeren ofte livsvigtige insulin. At det kan betale sig at producere sådanne medicinske produkter til vore livsstilssygdomme fremgår af Novo Nordisk' omsætning på 4,2 milliarder kroner i 1999 (se: http://www.novo.dk). I USA omsætter slankeindustrien årligt for 210 milliarder kroner (Skårderud (1999), s. 382). Hemmeligheden bag en sådan succes for den mindre seriøse del af slankeindustrien er, at den ikke har succes. Pulverkure og postordre-slankekure virker ikke, og derfor opretholder industrien det evige behov for sig selv. Den er ikke en del af løsningen men en del af problemet. 
26. Beck (1997), s. 75.

27. Dette forslag om rygeforbud på skolerne sigtede ikke blot mod lokaler og gangarealer indendøre, hvor det kunne forsvares med hensynet til dem, der udsættes for passiv rygning. Meningen var, at forbudet skulle gælde overalt på skolernes område også udendøre. Det er således ikke blot den sundhedsskadelige $\mathrm{r} \varnothing \mathrm{g}$, der skal forbydes, men selve det synlige symbol herpå, rygningen af cigaretterne selv.

28. Synspunkt i DR1s nyhedstime 7. september 2000.

29. Omsorgsvillen er det begreb, Verner Møller har anvendt for at pege på det fælles motiv, der synes at ligge bag de mange ulige investeringer i sundheden. Begrebet skal ikke forveksles med almindelig vilje til at drage omsorg. Det er ikke næstekærlighed eller viljen til at drage omsorg for hinanden, som det beskriver. Det peger derimod på en udbredt vilje til at drage omsorg for de abstrakte andre. Omsorgsvillen indebærer et forhold, der producerer en magtrelation og et magtforhold i og med omsorgsnyderens afhænden af ansvar og dermed magt til omsorgsyderen. Begrebet søger således at belyse det tilgrundsliggende motiv for diverse sundhedsmæssige tiltag, hvad enten de udbydes fra det privat-ideologiske eller det statsligtofficielle niveau. Møller (1999), s. $125 \mathrm{ff}$.

30. Jf. Schmidt og Kristensen (1988).

31. Antropologen Anne Knudsen (1996) har beskrevet, hvordan den indlysende afhændelse af magt på spidsfindig vis skjules og vikles ind i et virtuelt familiedrama, når man som patient er blevet indlagt. Hun analyserer situationen som en videreudvikling af forestillingen om »Familien Danmark «, hvor det gode og trygge familieliv efterlignes på samfundsplan. Da det er kvinderne, der dominerer $i$ alle omsorgserhvervene, de erhverv hvor borgeren møder samfundet, har de påtaget sig familiens moderrolle. Faderrollen er samfundet. Der er tale om en »fantomfader«, som er ham, der har lavet alle reglerne, som kvinderne efter bedste evne arbejder under. Derfor er det ikke kvindens skyld. »Hun gør bare, hvad hun får besked på. Sådan er det, overalt hvor borgerne møder samfundets omsorg. Det er ikke dem, der udfører arbejdet, der har bestemt, hvordan reglerne er. Det er simpelthen ikke kvindernes skyld.« Men bag enhver hjertevarm kvinde i omsorgssektoren står der skyggen af en hjerteløs mand og truer. Men den »... samfundsmæssige fantasifar behøver ikke at komme hjem til hospitalet, bistandskontoret og kommuneskolen for at blive vred på mor. Det er fuldt tilstrækkeligt, at hans skygge hænger kæmpestor over »familien««. Pointen er nu, at eftersom moderrollen er optaget af personalet og faderrollen af den fraværende patriark, er der kun én rolle de personer, der kommer i kontakt med samfundets omsorgssektor, kan udfylde. De kan være børn. At rollefordellingen kommer til at se således ud skyldes ikke blot, at omsorgspersonale næsten per definition er kvinder og derfor måske tilbøjeligt til at vælge kvinde-stereotyper, når arbejdslivet skal iscenesættes og begrebsliggøres. Den væsentligste grund er formentlig, at der i omsorgsinstitutionerne udøves magt. Og »... en af de mest effektive strategier til magtudøvelse uden konfrontation finder man i omfortolkningen af magtrelationen til en voksen-barn-relation. «Personalet kan derfor sige, at hvad de gør, gør de for min skyld. Det de gør er altså kærlighedsgerninger, så den, der møder omsorgssektoren, kan ikke være andet bekendt end at elske mor, personalet, til gengæld. Det er muligt at en sådan strategi ikke fører til, at personalet rent faktisk bliver elsket, men den gør det til sort utaknemmelighed at snakke om magt. Vi er alle i samme båd, derfor skal magten skjules, selv der hvor den er tydelig for enhver«. Alle citater fra kapitlet: »Far, mor og børn - for voksne«, Knudsen (1996).

32. Møller (1995), s. 31. Ilivelse er betegnelsen for et (post)moderne tilværelsesperspektiv. Set fra en idehistorisk synsvinkel har der fundet en perspektivforskydning sted fra det middelalderlige frelseperspektiv, over modernitetens overlevelsesperspektiv til postmodernitetens oplevelsesperspektiv. Ilivelsen betegner det tilværelsesperspektiv, som er fremtrædende i en tid, der har såvel moderne som postmoderne karaktertræk.

33. Han skriver: »Et afgørende træk ved den sunde fornuft ser ud til at bestå $i$, at den forlanger enhed mellem 'det æstetiske' og 'det moralske', og at argumentet for denne enhed i virkeligheden er enheden med 'det (medicinsk) videnskabelige'. Argumentet for det gode og det skønne er således dets sammenfald med det sande. Og det sande har en tid lang været sammenfaldende med det videnskabeligt rigtige, og som sådant været dominerende for enigheden. Aktuelt er det sunde imidlertid i færd med at erstatte det rigtige«. Schmidt (1994), s. 13

34. Et interessant spørgsmål er herefter, om sundheden, når den nu ikke længere er givet a priori, så til gengæld er givet aposteriori. Bliver vi ved billedet med joggeren, må vi sige, at der ikke kan være tale om aposteriori erkendelse i traditionel kantiansk forstand. Den empirisk erfarede sund- 
hed må nemlig gentages, i princippet, i det uendelige for vedblivende at (an)erkendes som reel. Når den ikke er givet a priori, kan den, på grund af dens processuelle karakter, kun erfares i gentagelsen.

35. Niels Kayser Nielsen (1991) har argumenteret for, hvordan denne selvovervågning manifesterer sig som skyldfølelse netop i forbindelse med mad og spisning. Hans pointe er, at hvor synden i middelalderen var tæt knyttet til seksualiteten, er den i dag tættere forbundet med maden. Dette skyldes seksualitetens parcellering i erotik, sex og forplantning, mens maden, med sit basale element af næring og sin tilknytning til den kropslige procesualitet, ikke blot er nydelse, hvorved den har bevaret tilknytningen til »begærskroppen«. I dag ved ethvert barn at nogle fødevarer er gode og sunde, andre er forkerte og usunde. At spise forkert er at synde. Og synder vi, kan vi gøre os skyld i sygdom. Vi synder, når vi spiser wienerbrød og napoleonskager, og vi har lidt dårlig samvittighed, når vi snyder os til en whisky eller et glas rødvin i utide. I amerikanske supermarkeder er der klistermærker på bananerne, ikke bare med »Low calorie« men også med »Guilt free«. Hvor middelaldermennesket måtte ty til bøn og afladsbreve må det (post)moderne menneske spise frugt og råkost og motionere for at få syndernes forladelse. Med sin enhed af lyst og nødvendighed og sin forbindelse til de basale livsvilkår, kan maden bruges i fortolkningsøjemed og som meningsstifter i forbindelse med sygdom. Parallelt hermed findes der i dag miljøer i Californien, hvor det er en større synd at spise et stykke chokolade end at være utro (Skårderud (1999), s. 388). Det taburiserede er transporteret fra én kropsåbning til en anden - fra skridtet til munden.

36. Foucault (1977).

37. Filmen kørte i danske biografer i sensommeren og efteråret 2000.

38. Schmidt (1994), s. 20.

39. Jf. Verner Møller (1999), Dopingdjacvlen - analyse af en hed debat, Gyldendal, København.

40. Som Ugebrevet Mandag Morgen kunne berette i august 2000 (nr. 29, d. 28. august 2000), så ser man i øjeblikket en eksplosivt voksende bevægelse af humanistiske og samfundsvidenskabelige forskere, der inddrager Darwins evolutionsteori i deres forskning for at belyse menneskets umoderne side. Udløbere af Darwins teorier om biologisk evolution kan bringe os en forståelse af menneskers (ir)rationelle adfærd i de højt specialiserede samfund, vi lever i. Som for andre arters vedkom- mende gælder det også for mennesket, at dets arvemateriale tilpasses de omgivelser, som det lever under. Men eftersom vi har tilbragt mindst 99 procent af vores udviklingshistorie i jæger-samler samfund, er vores hjerner - ligesom resten af vores krop - udviklet til at overleve og få børn under netop sådanne vilkår. Det er tanken, at disse forhold med fordel kan medinddrages i den sociologiske og kulturelle tænkning, der ønsker at komme til en forståelse af menneskets umoderne og irrationelle sider.

41. Regeringens folkesundhedsprogram 1999, s. 111.

42. Nogle vil endda hævde, at man for rygere (såvel som for narkomaner) ikke længere kan tale om frie valg. De har ikke længere friheden til at vælge smøgerne fra. Kæderygeren (og narkomanen) ejer ikke længere nogen fri vilje. Men man mister vel også friheden til at være ungkarl, hvis man gifter sig, friheden til at blive eliteidrætsudøver hvis man vælger at bruge sin tid på at studere, eller friheden til at blive hjemme, hvis man har besluttet sig for at rejse. Ethvert valg, vi træffer, afgør hvilke fremtidige valg, vi kan træffe. Dette er ikke et argument mod frie valg, men grunden til at vi skal tage valget alvorligt og være indstillet på at vise ansvar. Moralister af enhver slags kræver altid forbud i stedet for frie valg under ansvar. Filosoffen Fernando Savater kan citere Sankt Johannes Chrysostomos for allerede i det fjerde århundrede efter Kristi fødsel at have svaret sådanne moraliter således: »Jeg kan høre mænd råbe: 'Gid der ikke fandtes vin!' Hvor tankeløst! Er det måske vinen, der er skyld i misbruget? Hvis du i din fuldskab siger 'gid der ikke fandtes vin', skulle du også på grund af tyvene sige 'gid det ikke blev nat', eller 'gid det ikke blev lyst' af hensyn til angiverne, eller 'gid der ikke fandtes kvinder' på grund af ægteskabsbryderne.« Savater (1997), s. 77.

43. Man kan i denne henseende undre sig over det rimelige $i$, at privatpersoner anlægger erstatningssager mod tobaksindustrien, når man betænker, at sagsøgeren (som så mange andre) har ført et fysisk inaktivt liv. Man ved, at 25 ud af 100 rygere dør af følgesygdommene fra rygning. Men det gælder endvidere, at 33 ud af 100 fysisk inaktive $\mathrm{d} \varnothing \mathrm{r}$ af følgesygdommene ved inaktivitet. Det er altså farligere for helbredet at være inaktiv end at være ryger - isoleret set. Ville det, i dette perspektiv, ikke være langt rimeligere om folk anlagde sag mod de af deres gamle (idræts)lærere, som ikke i tilstrækkeligt omfang havde tilskyndet til fysisk aktivitet, fremfor at sagsøge tobaksindustrien? (Om vurdering af bidraget fra de enkelte 
risikofaktorer, se Haapanen-Niemi et al. (1999)). Det hjælper ikke stort, at kernen i anklagen går på, at tobaksindustrien ikke har oplyst befolkningen om sundhedsfarerne ved at ryge trods bedre vidende. Det ville svare til, at en udbrændt alkoholiker anlagde sag mod spiritusproducenterne for ikke at have oplyst om sundhedsfarerne ved alkohol trods bedre vidende.

44. Endnu et eksempel får man ved at betragte den defensive strategi, man generelt - i hele EU - har valgt overfor de tusindvis af sundhedsskadelige stoffer, som industrien anvender. Dette blev vist $\mathrm{i}$ en række indslag fra DR i oktober 2000 (P1 bladet Emil i Weekendavisen 29. september samt TV og radioudsendelser ons. 11. okt.). I dag er mange forbrugsvarer fremstillet ved hjælp af en række kunstigt tilvirkede kemiske stoffer, hvis eventuelle sundhedsskadelige effekter vi ikke kender. Sådan har det været i mange år, hvorfor EU i 1981 bad industrien registrere de ca. 20.000 kemikalier, man regnede med var i anvendelse. At man ikke forb $\varnothing \mathrm{d}$ eller krævede dokumentation for det sundhedsmæssigt forsvarlige i fortsat anvendelse af kemikalierne, skyldtes både forbrugernes og industriens interesser. Den europæiske kemiindustri er verdens største og derfor meget magtfuld. Og det ville forårsage forbrugeroprør, hvis de europæiske forbrugere blev frataget alle de kemibaserede, prisbillige produkter. Denne defensive strategi viste sig at resultere $\mathrm{i}$ industriens registrering af ikke mindre end 100.106 kemikalier. Hvilket gav industrien et gigantisk reservoir af legaliserede kemikalier, der har ført til, at kun 3000 nye er blevet anmeldt siden 1981. Da man i 1990'erne begyndte at interessere sig for disse kemikalier, blev man klar over, at for $86 \%$ vedkommende havde man ingen eller kun ringe viden om deres giftighed. I 1993 besluttede EUs miljøministre derfor at kortlægge stoffernes farlighed. I dag har man afsluttet undersøgelserne af fire ud af de 100.106 kemikalier! Samtidig ved vi, at hver europæer i dag går rundt med ca. 500 kunstige kemikalier i kroppen. Kemikalier hvis farlighed vi altså ikke kender.

45. Når den amerikanske tobaksindustri for indeværende beskydes kraftigt, synes det at bekræfte denne tanke. Men den moral, der bærer kritikken frem, er diskriminerende, hvorfor offeret kun er delvist. Anklagerne på den hjemlige front følges nemlig ikke op af et forbud mod eksport af det sundhedstruende produkt. Anklagerne lægger således intet til hinder for, at den enorme eksport af cigaretter til bl.a. Afrika kan fortsætte, mens industrien bekæmpes på hjemmemarkedet.
46. Ordet Jagannath stammer fra hindi, »Verdens Herre $«$ og er en betegnelse for guden Krisna. Hvert år blev et billede af guden trukket gennem gaderne på en stor vogn, som tilbederne siges at have kastet sig selv ind under for at blive knust af hjulene. Giddens (1994), s. 120.

47. Giddens (1994) s. 120-121.

48. Regeringens folkesundhedsprogram 1999, s. 49.

49. Se eksempelvis Paffenbarger et al. (1994).

50. Sundhedsstyrelsen (1997).

51. Sundhedsstyrelsen (1997), s. 4 og s. 17

52. Blair \& Connelly (1996).

53. Regeringens folkesundhedsprogram 1999, s. 53.

54. DIF modtog i regnskabsåret 1997/1998 234,7 mio. kr. fra tips- og lottomidlerne. Herudover havde de renteindtægter på 4,9 mio. kr., altså i alt 239,6 mio. kr. Af disse skal 12 procent, ifølge DIFs love, tilfalde Team Danmark og DBU, svarende til 18,3 mio. kr. til Team Danmark i bemeldte regnskabsår. Information fra: http://www.dif.dk/ emmma/html/omDIF_oekonomi/omdif_team DK.asp.

55. Informationerne er hentet fra http://www.teamdk.dk/.

56. Folketingstidende, Forhandlinger 1975/76, 2 sp. 4912.

57. Folketingstidende, Forhandlinger 1983/84, sp. 4791.

58. Møller (1999), s. 129.

59. I efteråret 2000 har DR således valgt at bruge licenspenge på at lade den selvbestaltede kok Anne Larsen, i programmet »Max 30\%«, vise hvordan man efter endt stegning og frahældning af stegeskyen kan skylle sit hakkekød under den varme hane for at få de sidste rester af fedt fjernet fra k $\emptyset$ det. Den gastronomiske side af sagen synes Anne Larsen ikke at være så bekymret for, når blot vi undgår fedtet. Den lipofobi, Anne Larsen her er eksponent for, synes at være en af de mest udbredte fobi'er i vor tid. Således er fedt i dag mere et begreb af moralsk karakter end navnet på et nødvendigt næringsstof. Kropsfedtet indeholder den (post)moderne kulturs myter, tabuer og regler for kategorisering og moralsk fordømmelse. Kampen mod fedtet er et magisk ritual, der gør indsigelse mod Max Webers udsagn om, at kulturen er blevet »affortryllet« (Månson (2000), s. 92). Vi står i dag blot med en alternativ fortryllelse. Hverdagsreligiøsiteten forklæder sig som ikke-religiøsitet og som helt igennem verdslig. Som den slanke krop er en kropsliggørelse af det socialt hellige, er fedtet blevet en negativ relikviekult - det er konkretiseringen af den verdslige djævel. 


\section{Litteratur}

Beck, Ulrich, 1997, Risikosamfundet - på vej mod en ny modernitet, Hans Reitzels Forlag, København.

Bjerregaard, Peter, 1994, Samfundsmassige og sociale forhold-middellevetid og dødelighed, 6. delrapport fra Sundhedsministeriets Middellevetidsudvalg, en litteraturgennemgang, DIKE og Sundhedsministeriets Middellevetidsudvalg, København.

Bjerregaard, Peter og Juel, Knud, 1993, Middellevetid og dødelighed, 1. delrapport fra Sundhedsministeriets Middellevetidsudvalg, DIKE og Sundhedsministeriets Middellevetidsudvalg, København.

Blair, S. N., and Connelly J. C., 1996, »How Much Physical Activity Should We Do? The Case for Moderate Amounts and Intensities of Physical Activity« i: Research Quarterly for Exercise and Sport, 67(2), s. 193-205.

Dubos, René J., 1960, Drømmen om sundhed, Hans Reitzels Forlag, København.

Elsas, Peter, 1993, Sundhedspsykologi. Et ny fag mellem humaniora og naturvidenskab, Gyldendal, København.

Foucault, Michel, 1977, Overvågning og straf - det moderne faengselsvasens historie, Rhodos Radius, København.

Giddens, Anthony, 1994, Modernitetens konsekvenser, Hans Reitzels Forlag, København.

Haapanen-Niemi, N., Vuori, I., Pasanen, M., 1999, »Public health burden of coronary heart disease risk factors among middle-aged and elderly men «, i: Preventive Medicine, 28(4), s. 343-348.

Ingerslev, Madsen og Andersen, 1994, Sociale forskelle i dødeligheden i Danmark, 3. delrapport fra sundhedsministeriets Middellevetidsudvalg, DIKE og Sundhedsministeriets Middellevetidsudvalg, København.

Knudsen, Anne, 1996, Her går det godt, send flere penge, Gyldendal, København.

Møller, Verner, 1995, »Den (ir)rationelle virkelighed «, Tendens, 2, s. 19-36, København.

Møller, Verner, 1997, Sundhed og idrat-Kulturanalyser til indkredsning af sundhedsaspektet $i$ idratten, ph.d. afhandling, Odense Universitet.

Møller, Verner, 1999, Sundhed og idrat - Kulturanalyser til indkredsning af sundhedsaspektet $i$ idratten, ph.d. afhandling, Odense Universitetsforlag.
Mørch, Søren, 1996, Den sidste Danmarkshistorie 57 fortallinger fra faedrelandets historie, Gyldendal, København.

Månson, Per, 2000, »Max Weber«, i: Heine Andersen og Lars Bo Kaspersen (red.), Klassisk og moderne samfundsteori, 2. rev. udgave, Hans Reitzels Forlag, København.

Nielsen, Niels Kayser, 1991, »Sex, synd og råkost«, i: Niels Kayser Nielsen, Michael Andersen \& Jørn Hansen (red.), Kroppens spejl - en antologi om idrat og sundhed, Odense Universitetsforlag.

Paffenbarger, Ralph S., Jr., Kampert, J. B., Lee, I-M, Hyde, R. T., Leung, R. W. og Wing, A. L., 1994, »Changes in physical activity and other lifeway patterns influencing longevity«, i: Medicine and Science in Sport and Exercise, 26(7), s. 857-865.

Qvarsell, Roger, 1989, »Människan och hennes hälsa: Om hälobegreppets och häloupplysningens idéhistoria«, i: Sten Philipson \& Nils Uddenberg (red.): Hälsa som livsmening, Natur och Kultur, Stockholm.

Regeringens folkesundhedsprogram 1999-2008. Et handlingsorienteret program for sundere rammer $i$ hverdagen, 1999, 2. oplag, Sundhedsministeriet, København.

Savater, Fernando, 1997, Mod til at opdrage, Forlaget Forum, København.

Schmidt, Lars-Henrik og Kristensen, Jens Erik, 1986, Lys, luft og renlighed - den moderne socialhygiejnes fødsel, Akademisk Forlag, København.

Schmidt, Lars-Henrik og Kristensen, Jens Erik, 1988, »Den forebyggende tanke«, i Social Kritik, nr. 3, vol. 1, s.: 56-59.

Schmidt, Lars-Henrik, 1994, »Den arme synder - utidige bemærkninger om tidens sunde fornuft $«$, i: Verner Møller, Jørgen Poulsen og Kurt Lüders (red.): Hooked - om vanvid og astetik $i$ sport og kropskultur, Odense universitetsforlag.

Skårderud, Finn, 1999, Uro - en rejse i det moderne selv, Tiderne Skifter, København.

Sundhedsstyrelsen, 1997, På vej mod en sundere arbejdsplads - Fokus på motion, udarbejdet af Finn Berggren og Thomas Skovgaard, Inst. for Idræt og Biomekanik, Odense Universitet. 